\title{
A short synthesis of two analogues of Parvaquone
}

\author{
Cesar R. Solorio-Alvarado ${ }^{\S}$, Eduardo Peña-Cabrera*\$ ${ }^{\S}$, and Cecilio Alvarez-Toledano \\ ${ }^{\S}$ Facultad de Química. Universidad de Guanajuato. Col. Noria Alta S/N. Guanajuato, GTO. \\ Mexico 36050 \\ Instituto de Química UNAM, Cto. Exterior, Cd. Universitaria, 04510 Coyoacán, México DF \\ E-mail: eduardop@quijote.ugto.mx
}

(received 13 Feb 04; accepted 14 Apr 04; published on the web 29 Apr 04)

\begin{abstract}
The synthesis of two analogues of parvaquone was accomplished starting form diisopropyl squarate. In addition to the classical conditions for ring expansion-cyclization process, a microwave-assisted reaction was introduced.
\end{abstract}

Keywords: Parvaquone, squaric acid ester, 2-hydroxy-1,4-naphthoquinones, microwaves

\section{Introduction}

The relevance of 2-hydroxy-1,4-naphthoquinones is well established. This class of compounds displays a broad spectrum of important biological activities, such as antiprotozoal, ${ }^{1}$ antibacterial, ${ }^{2}$ antimalarial, ${ }^{3}$ pesticidal, ${ }^{4}$ and antileishmanial ${ }^{5}$ activity among others. Moreover, hydroxynaphthoquinones have been used as synthetic intermediates in the preparation of more elaborate compounds. ${ }^{6}$ Although there are several different methods to prepare this type of compounds, ${ }^{7}$ the importance of known and newly reported naphthoquinoid structures (e.g. Lactonamycin $^{8}$ and Hybocarpone $\left.{ }^{9}\right)$ justifies the search for new and more efficient methods to build molecules of such complexity.<smiles>O=C1C(O)=C(C2CCCCC2)C(=O)c2ccccc21</smiles>

Parvaquone (1) 
Parvaquone (1) is another example of a 2-hydroxy-1,4-naphthoquinone with significant properties, i.e., it has been used against Theileria parva, a parasite that causes East Coast Fever. $^{10}$

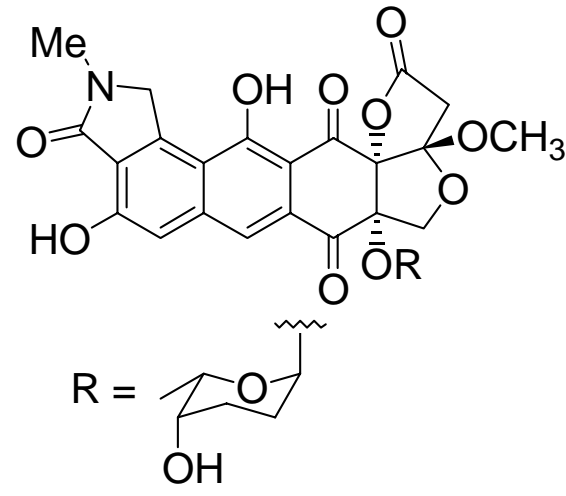<smiles>CCC12OC3(O)C(=O)c4c(O)c(O)c(C)c(O)c4C(=O)C3(O)C1(CC)C(=O)c1c(O)c(O)c(C)c(O)c1C2=O</smiles>

$(+)$-Lactonamycin

Our laboratory recently reported a short preparation of (1). ${ }^{11}$ The squaric acid chemistry developed mainly by Liebeskind and Moore ${ }^{12}$ was employed to accomplish such synthesis. In order to demonstrate the versatility of this methodology, we wish to report the preparation of two analogues of parvaquone.

\section{Results and Discussion}

The synthetic route involved the addition of commercially available cyclohexylmagnesium chloride to diisopropyl squarate $2^{13}$ at low temperature followed by trifluoroacetic anhydride (TFAA) quench ${ }^{14}$ to obtain directly cyclohexyl-substituted squarate 3 in $93 \%$ yield (eq. 1).

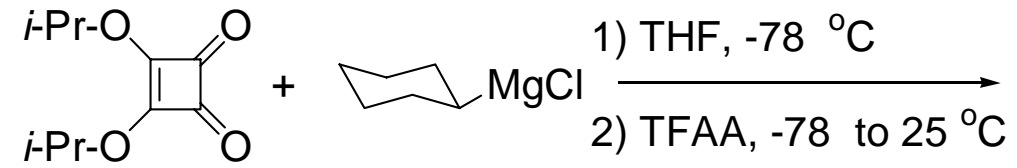

2

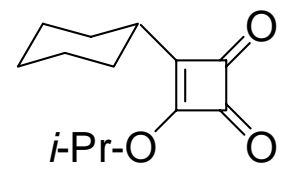

$3,93 \%$

The remaining steps in our synthetic route are depicted in Scheme 1.

Addition or aryllithium derivatives (generated by metal-halogen exchange of iodides $\mathbf{4}$ and 5) to squarate 3 at $-78{ }^{\circ} \mathrm{C}$, followed by an aqueous $\mathrm{NH}_{4} \mathrm{Cl}$ quench gave adducts 6 and 7 in $42 \%$ yield and 34\% yield respectively. Despite several efforts, we were unable to increase the yield of this step, presumably due to the fact that tertiary alcohols $\mathbf{6}$ and $\mathbf{7}$ are particularly prone to hydrolysis in the presence of traces of acid. ${ }^{15}$ Under these conditions, hydroxyl ionization would form a carbocation that would be strongly stabilized by both the electron-rich phenyl ring, and its 
allylic character. Then, the neat adducts 6 and 7 were thermolyzed at $155^{\circ} \mathrm{C}$ for $5 \mathrm{~min}$. to give the corresponding hydroquinones, which, on exposure to air, readily oxidized to naphthoquinones 8 (75\% yield from 6) and 9 (76\% yield from 7) in a very efficient manner. The final step of the synthesis was carried out by deprotection of 8 and 9 with 2.5 eq. of $\mathrm{BBr}_{3}$ at $-78{ }^{\circ} \mathrm{C}$ to give hydroxynaphthoquinones 10 (92\% yield) and 11 (84\% yield). Remarkably, the methoxy group of 8 remained intact during the deprotection step as evidenced by the signal at $3.96 \mathrm{ppm}(3 \mathrm{H})$ in the ${ }^{1} \mathrm{H}$ NMR spectrum.

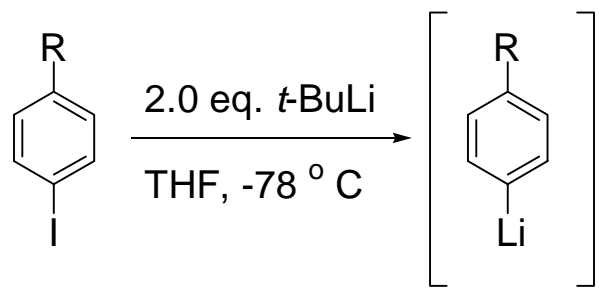

1) $3(0.9 \mathrm{eq}),-78{ }^{\circ} \mathrm{C}, \mathrm{THF}$

2) aq. $\mathrm{NH}_{4} \mathrm{Cl},-78$ to $25{ }^{\circ} \mathrm{C}$

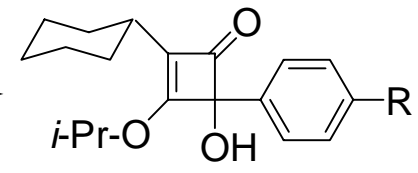

6, $42 \% \mathrm{R}=\mathrm{Me}$

4, $\mathrm{R}=\mathrm{Me}$

5, $\mathrm{R}=\mathrm{OMe}$

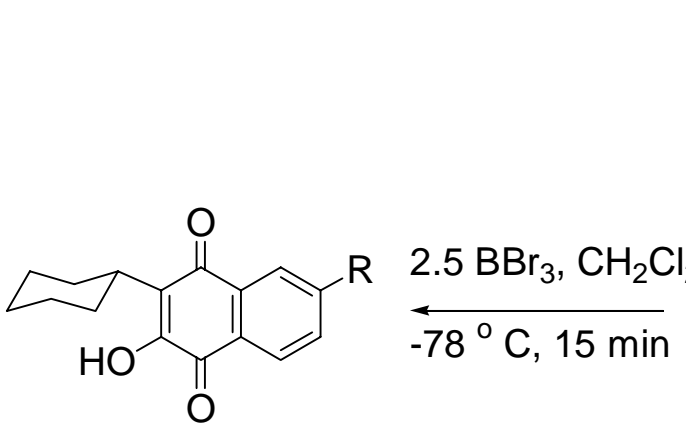

$10,92 \% \mathrm{R}=\mathrm{Me}$

$11,84 \% \mathrm{R}=\mathrm{OMe}$<smiles>[R]c1ccc2c(c1)C(=O)C(C1CCCCC1)=C(O[Po])C2=O</smiles><smiles>[R]c1ccc2c(O)c(O[Pb])c(C3CCCCC3)c(O)c2c1</smiles>

8, 75\% (from 6) $\mathrm{R}=\mathrm{Me}$

9, 76\% (from 7) $\mathrm{R}=\mathrm{OMe}$

Scheme 1. Completion of the synthesis of parvaquone analogues $\mathbf{1 0}$ and $\mathbf{1 1 .}$

In searching for a more efficient way to thermolyze 6 and 7, it was decided to expose them to microwave radiation using a simple household microwave oven. To our delight, after exposing neat $\mathbf{6}$ and 7 to microwave radiation for $2 \mathrm{~min}$, deprotected hydroxynaphthoquinones $\mathbf{1 0}$ and 11 were isolated in $29 \%$ yield and $40 \%$ yield, respectively (eq. 2 ).

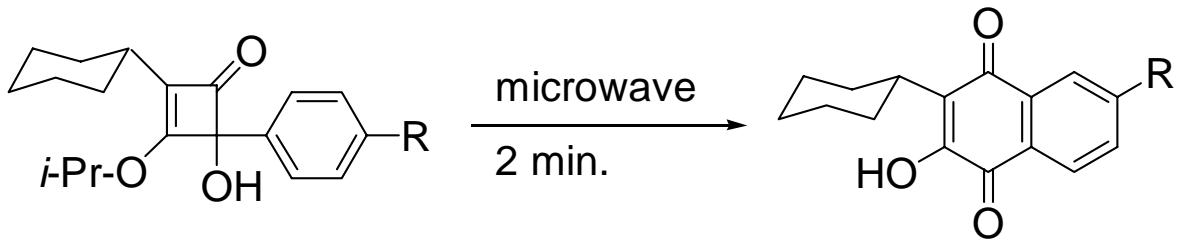

6, $R=M e$
7, $R=O M e$
$10,29 \% \mathrm{R}=\mathrm{Me}$

11, $40 \% \mathrm{R}=\mathrm{OMe}$ 
Even though no study of the reaction mechanism of the microwave-promoted generation of 10 and $\mathbf{1 1}$ has been carried out, it is presumed that it is the same as that accepted for the conventional thermolysis reaction. The greater lability of the $i$-Pr-protected enol-ether fragment (in 8 and 9) that was observed under the $\mathrm{BBr}_{3}$ deprotection conditions was observed in this protocol as well. It is worth mentioning that despite the apparently low yields, they represent the overall yields of three reactions, i.e., cyclization, oxidation and deprotection. Thus, under these conditions, a $29 \%$ yield of 10 represents a $66 \%$ yield for each individual step, and a $40 \%$ yield of 11 represents a 74\% yield for each step.

In conclusion, it has been demonstrated that the chemistry of squaric acid esters lends itself for the synthesis of highly substituted 2-hydroxynaphthoquinones as demonstrated by the expedite synthesis of two derivatives of parvaquone $\mathbf{1 0}$ and 11. Moreover, a new microwaveinduced cyclization method was introduced that allowed for the selective deprotection of the $i$ propyl-substituted oxygen.

\section{Experimental Section}

General Procedures. ${ }^{1} \mathrm{H}$ NMR spectra were recorded on a Varian Gemini $200(200 \mathrm{MHz})$ spectrometer in deuteriochloroform $\left(\mathrm{CDCl}_{3}\right)$ with either tetramethylsilane (TMS) $(0.0 \mathrm{ppm})$ or chloroform $(7.26 \mathrm{ppm})$ as internal reference unless otherwise indicated. Data are reported in the following order: chemical shift in ppm $(\delta)$, multiplicities (br (broadened), s (singlet), d (doublet), $\mathrm{t}$ (triplet), q (quartet), sex (sextet), hep (heptet), m (multiplet), exch (exchangeable), app (apparent)), coupling constants, $J(\mathrm{~Hz})$, and integration. Infrared spectra were recorded on a Perkin Elmer FTIR 1600 series spectrophotometer. Peaks are reported $\left(\mathrm{cm}^{-1}\right)$ with the following relative intensities: $\mathrm{s}$ (strong, 67-100\%), m (medium, 40-67\%), and w (weak 20-40\%).

Analytical thin-layer chromatography was performed on Merck silica gel plates with F-254 indicator. Visualization was accomplished by UV light, iodine, phosphomolybdic acid or $p$ anisaldehyde solutions. THF was distilled from sodium and benzophenone and stored under nitrogen.

3-Cyclohexyl-4-isopropoxycyclobuten-1,2-dione (3). Cyclohexylmagnesium chloride (26 mmol of a $2 \mathrm{M}$ ether solution) was added via syringe to a cold $\left(-78^{\circ} \mathrm{C}\right) \mathrm{THF}(10 \mathrm{~mL})$ solution of diisopropylsquarate 2 (4.0 g, $20.2 \mathrm{mmol}$, 1,3 equiv.). After $20 \mathrm{~min}$, TFAA (3.3 mL, $20.2 \mathrm{mmol}$ ) was added at $-78{ }^{\circ} \mathrm{C}$ via syringe, the cooling bath was removed and the mixture was allowed to reach room temperature. An aq. saturated $\mathrm{NH}_{4} \mathrm{Cl}$ solution was added $(20 \mathrm{~mL})$ and then the crude material was extracted with ether $(3 \times 15 \mathrm{~mL})$, dried over anhyd. $\mathrm{MgSO}_{4}$ and filtered. The solvent was removed in vacuo to give a yellow oil. The product $(4.2 \mathrm{~g}, 93 \%)$ was obtained as a low-melting solid. TLC (silica gel, 20\% ethyl acetate/hexanes $\mathrm{R}_{f}=0.46$ ); chromatographic purification ( $1 \times 15 \mathrm{~cm}$, ethyl acetate/hexanes gradient); mp 34-35 ${ }^{\circ} \mathrm{C}$; IR (KBr, cm $\left.{ }^{-1}\right) 2933$ (s), 2854 (s), 1794 (s), 1753 (s), 1588 (s); ${ }^{1} \mathrm{H}$ NMR (CDCl, $\left.200 \mathrm{MHz}\right) \delta 5.41$ 
(sept, $J=6.2 \mathrm{~Hz}), 2.75(\mathrm{tt}, J=3.6,10.8 \mathrm{~Hz}, 1 \mathrm{H}), 1.93-1.85(\mathrm{~m}, 2 \mathrm{H}), 1.80-1.50(\mathrm{~m}, 6 \mathrm{H}), 1.45$ (d, $J=6.2 \mathrm{~Hz}, 6 \mathrm{H}), 1.42-1.28(\mathrm{~m}, 2 \mathrm{H}) ;{ }^{13} \mathrm{C} \mathrm{NMR}\left(\mathrm{CDCl}_{3}, 75.5 \mathrm{MHz}\right) \delta 197.5,195.3,194.8,188.2$, 79.1, 36.5, 29.0, 25.7, 25.6, 23.0. Anal. Calcd. for $\mathrm{C}_{13} \mathrm{H}_{18} \mathrm{O}_{3}$ : C, 70.24; H, 8.16. Found: C, 70.15; $\mathrm{H}, 8.33$.

2-Cyclohexyl-3-isopropyl-4-aryl-2-cyclobutene-1-ones 6 and 7. To the corresponding $p$ substituted phenyl iodide ( 1 equiv.) in THF was added $t$-BuLi ( 2 equiv.) at $-78{ }^{\circ} \mathrm{C}$ via syringe. The mixture was stirred at $-78{ }^{\circ} \mathrm{C}$ for $1 \mathrm{~h}$. The aryllithium was added to a THF solution of $3(0.9$ equiv.) at $-78{ }^{\circ} \mathrm{C}$ via cannula. After $15 \mathrm{~min}$ all of $3 \mathrm{had}$ reacted. The reaction mixture was quenched with an aq. saturated $\mathrm{NH}_{4} \mathrm{Cl}$ solution at $-78{ }^{\circ} \mathrm{C}$ and then the cooling bath was removed allowing it to warm up to room temperature. The crude reaction mixture was extracted with ether ( 3 x $20 \mathrm{~mL}$ ), dried over anhyd. $\mathrm{MgSO}_{4}$ and filtered. The solvent was removed in vacuo and the remaining material was purified by flash chromatography (silica gel, $1.5 \mathrm{x} 12 \mathrm{~cm}$, ethyl acetate/hexanes gradient). Data for 6: $42 \%$ white solid, $\mathrm{mp} 141-143{ }^{\circ} \mathrm{C} ; \mathrm{R}_{f}=0.25(20 \%$ EtOAc/hexanes); IR (KBr, cm $\left.{ }^{-1}\right) 3168$ (m), 2980 (m), 2930 (m), 2849 (m), 1749 (m), 1604 (s), $1102(\mathrm{~m}) ;{ }^{1} \mathrm{H}$ NMR $\left(\mathrm{CDCl}_{3}, 200 \mathrm{MHz}\right) \delta 7.35$ (d, $\left.J=8.4 \mathrm{~Hz}, 2 \mathrm{H}\right), 7.17$ (d, $\left.J=8.4 \mathrm{~Hz}, 2 \mathrm{H}\right), 4.65$ (sept., $J=6.2 \mathrm{~Hz}, 1 \mathrm{H}), 2.35(\mathrm{~s}, 3 \mathrm{H}), 2.32$ (tt, $J=3.6,11 \mathrm{~Hz}, 1 \mathrm{H}), 1.96-1.44(\mathrm{~m}, 7 \mathrm{H}), 1.36(\mathrm{~d}, J=$ $6.2 \mathrm{~Hz}, 3 \mathrm{H}), 1.28(\mathrm{bs}, 3 \mathrm{H}), 1.06(\mathrm{~d}, J=6.2 \mathrm{~Hz}, 3 \mathrm{H}) ;{ }^{13} \mathrm{C} \mathrm{NMR}\left(\mathrm{CDCl}_{3}, 75.5 \mathrm{MHz}\right) \delta 190.0$, 180.4, 137.9, 134.4, 133.7, 129.5, 125.5, 92.8, 66.1, 33.8, 30.5, 26.0, 23.0, 22.7, 21.4, 15.5. Anal. Calcd. for $\mathrm{C}_{20} \mathrm{H}_{26} \mathrm{O}_{3}$ : C, 76.40; H, 8.33. Found: C, 76.01; H, 8.56. Data for 7: 34\% white solid, $\mathrm{mp} 125-127{ }^{\circ} \mathrm{C} ; \mathrm{R}_{f}=0.2$ (20\% EtOAc/hexanes); IR (KBr, cm $\left.{ }^{-1}\right) 3200(\mathrm{~m}), 2978(\mathrm{~m}), 2930(\mathrm{~s})$, 2852 (m), 1746 (s), 1603 (s), 1247 (s); ${ }^{1} \mathrm{H} \mathrm{NMR}\left(\mathrm{CDCl}_{3}, 200 \mathrm{MHz}\right) \delta 7.38$ (d, J=8.9 Hz, 2H), $6.88(\mathrm{~d}, J=8.9 \mathrm{~Hz}, 2 \mathrm{H}), 4.66$ (sept., $J=6.2 \mathrm{~Hz}, 1 \mathrm{H}), 2.81$ (s, 3H), 2.31 (tt, $J=3.5,11.2 \mathrm{~Hz}, 1 \mathrm{H}$ ), 1.96-1.05 (m, 7H), $1.36(\mathrm{~d}, J=6.2 \mathrm{~Hz}, 3 \mathrm{H}), 1.27(\mathrm{bs}, 3 \mathrm{H}), 1.05(\mathrm{~d}, J=6.2 \mathrm{~Hz}, 3 \mathrm{H}) ;{ }^{13} \mathrm{C} \mathrm{NMR}$ $\left(\mathrm{CDCl}_{3}, 75.5 \mathrm{MHz}\right) \delta 190.9,181.2,159.4,133.5,129.7,127.0,114.1,92.5,77.9,55.4,33.7$, 30.5, 26.0, 23.0, 22.7. Anal. Calcd. for $\mathrm{C}_{20} \mathrm{H}_{26} \mathrm{O}_{4}$ : C, 72.70; H, 7.93. Found: C, 72.44; H, 8.35.

2-Cyclohexyl-3-isopropoxy-7-aryl-1,4-naphthoquinones 8 and 9. Neat 6 or 7 was placed into a capped vial and then immersed in a preheated sand-bath at $155{ }^{\circ} \mathrm{C}$. After $5 \mathrm{~min}$, TLC (silica gel, 20\% EtOAc/hexanes, UV), reveals that all of the starting material had reacted and that a mixture of two compounds was formed, namely, the naphthoquinone and the corresponding hydroquinone. The vial was allowed to cool and the crude mixture was diluted with ether $(20 \mathrm{~mL})$, transferred into a round-bottomed flask and stirred in the open air. After $1 \mathrm{~h}$ the hydroquinone transformed into the naphthoquinone as evidenced by TLC. The solvent was removed in vacuo and the remaining material was purified by column chromatography (silica gel, EtOAc/hexanes gradient). Data for 8: 75\% yellow fluorescent oil; $\mathrm{R}_{f}=0.8(20 \%$ EtOAc/hexanes) (for the corresponding hydroquinone $\left.\mathrm{R}_{f}=0.7\right)$ : IR $\left(\mathrm{KBr}, \mathrm{cm}^{-1}\right) 3156(\mathrm{w}), 2929$ (w), 2854 (w), 1749 (s), 1665 (m), 1099 (m); ${ }^{1} \mathrm{H}$ NMR $\left(\mathrm{CDCl}_{3}, 200 \mathrm{MHz}\right) \delta 7.88$ (d, J=5.2 Hz, $1 \mathrm{H}), 7.83(\mathrm{~s}, 1 \mathrm{H}), 7.45(\mathrm{~d}, J=5.2 \mathrm{~Hz}, 1 \mathrm{H}), 5.06$ (sept, $J=4.1 \mathrm{~Hz}, 1 \mathrm{H}), 3.12(\mathrm{tt}, J=2.1,8.1 \mathrm{~Hz}$, $1 \mathrm{H}), 2.47(\mathrm{~s}, 3 \mathrm{H}), 2.12-1.48(\mathrm{~m}, 7 \mathrm{H}), 1.35(\mathrm{dd}, J=1.0,4.4 \mathrm{~Hz}, 6 \mathrm{H}), 1.33(\mathrm{bs}, 3 \mathrm{H}) ;{ }^{13} \mathrm{C}$ NMR $\left(\mathrm{CDCl}_{3}, 75.5 \mathrm{MHz}\right) \delta 186.0,182.3,156.7,145.0,140.1,133.8,132.7,129.4,126.8,126.3,76.0$, 36.6, 30.2, 27.2, 26.3, 23.1, 22.1; HRMS (EI) calcd. for $\mathrm{C}_{20} \mathrm{H}_{24} \mathrm{O}_{3} 312.1275$, found 312.1278. 
Data for 9: $76 \%$ bright yellow solid; $\mathrm{mp} 80-81{ }^{\circ} \mathrm{C} ; \mathrm{R}_{f}=0.83$ (20\% EtOAc/hexanes) (for the corresponding hydroquinone $\left.\mathrm{R}_{f}=0.55\right)$; IR $\left(\mathrm{KBr}, \mathrm{cm}^{-1}\right) 2925(\mathrm{~m}), 2851(\mathrm{~m}), 1651(\mathrm{~m}), 1585(\mathrm{~s})$, $1243(\mathrm{~m}) ;{ }^{1} \mathrm{H} \mathrm{NMR}\left(\mathrm{CDCl}_{3}, 200 \mathrm{MHz}\right) \delta 7.94(\mathrm{~d}, J=8.4 \mathrm{~Hz}, 1 \mathrm{H}), 7.49$ (d, $\left.J=2.6 \mathrm{~Hz}, 1 \mathrm{H}\right), 7.12$ $(\mathrm{dd}, J=2.6,8.6 \mathrm{~Hz}, 1 \mathrm{H}), 5.08$ (sept, $J=6.2 \mathrm{~Hz}, 1 \mathrm{H}), 3.93$ (s, 3H), 3.11 (tt, $J=3.3,12.1 \mathrm{~Hz}, 1 \mathrm{H}$ ), $2.11-1.45(\mathrm{~m}, 10 \mathrm{H}) ; 1.36(\mathrm{~d}, J=6.2 \mathrm{~Hz}, 6 \mathrm{H}) ;{ }^{13} \mathrm{C} \mathrm{NMR}\left(\mathrm{CDCl}_{3}, 75.5 \mathrm{MHz}\right) \delta 185.7,181.4$, 164.3, 157.1, 139.8, 135.0, 128.5, 125.1, 119.7, 109.8, 76.2, 56.0, 36.6, 30.3, 27.2, 26.3, 23.2. Anal. Calcd. for $\mathrm{C}_{20} \mathrm{H}_{24} \mathrm{O}_{4}$ : C, 73.15; H, 7.37. Found: C, 73.09; H, 7.88.

2-Cyclohexyl-3-hydroxy-7-aryl-1,4-naphthoquinones 10 and 11 . To a cold $\left(-78{ }^{\circ} \mathrm{C}\right) \mathrm{CH}_{2} \mathrm{Cl}_{2}$ solution of naphthoquinones 8 or 9 ( 1 equiv.) under nitrogen, was added a $1 \mathrm{M} \mathrm{CH}_{2} \mathrm{Cl}_{2}$ solution of $\mathrm{BBr}_{3}$ (2.5 equiv) via syringe dropwise. After $20 \mathrm{~min}$, the reaction was quenched with water at $-78{ }^{\circ} \mathrm{C}$, the cooling bath was removed and then the mixture was extracted with $\mathrm{CH}_{2} \mathrm{Cl}_{2}(3 \mathrm{x}$ $20 \mathrm{ml}$ ). The organic extracts were dried (anhyd. $\mathrm{MgSO}_{4}$ ) filtered, and the solvent removed in vacuo. The remaining material was purified by column chromatography (silica gel, EtOAc/hexanes gradient). Data for 10: $92 \%$ dark yellow solid, mp $177-178{ }^{\circ} \mathrm{C} ; \mathrm{R}_{f}=0.40(20 \%$ EtOAc/hexanes); IR (KBr, cm $\left.{ }^{-1}\right) 3358(\mathrm{~m}), 2914(\mathrm{~m}), 2850(\mathrm{~m}), 1657$ (s), 1635 (s), 1597 (s); ${ }^{1} \mathrm{H}$ $\operatorname{NMR}\left(\mathrm{CDCl}_{3}, 200 \mathrm{MHz}\right) \delta 7.95(\mathrm{~d}, J=7.8 \mathrm{~Hz}, 1 \mathrm{H}), 7.91(\mathrm{~s}, 1 \mathrm{H}), 7.47(\mathrm{~s}, 1 \mathrm{H}), 7.44(\mathrm{~s}, 1 \mathrm{H}), 3.06$ $(\mathrm{tt}, J=3.4,12.2 \mathrm{~Hz}, 1 \mathrm{H}), 2.5(\mathrm{~s}, 3 \mathrm{H}), 2.10-1.2(\mathrm{~m}, 10 \mathrm{H}) ;{ }^{13} \mathrm{C} \mathrm{NMR}\left(\mathrm{CDCl}_{3}, 75.5 \mathrm{MHz}\right) \delta 185.1$, $181.9,153.1,146.6,133.6,133.3,127.7,127.1,126.4,35.2,29.4,27.0,26.2,22.3$; HRMS (EI) calcd. for $\mathrm{C}_{17} \mathrm{H}_{18} \mathrm{O}_{3} 270.1256$, found 270.1259. Data for 11: 84\% dark yellow solid, mp 138$139{ }^{\circ} \mathrm{C} ; \mathrm{R}_{f}=0.58$ (20\% EtOAc/hexanes); IR (KBr, cm $\left.{ }^{-1}\right) 3327(\mathrm{~m}), 2034(\mathrm{~m}), 2850(\mathrm{~m}), 1651(\mathrm{~s})$, $1590(\mathrm{~m}) ;{ }^{1} \mathrm{H} \mathrm{NMR}\left(\mathrm{CDCl}_{3}, 200 \mathrm{MHz}\right) \delta 8.01(\mathrm{~d}, J=8.4 \mathrm{~Hz}, 1 \mathrm{H}), 7.58(\mathrm{~d}, J=2.6 \mathrm{~Hz}, 1 \mathrm{H}), 7.56$ $(\mathrm{s}, 1 \mathrm{H}), 7.12(\mathrm{dd}, \mathrm{J}=2.8,8.6 \mathrm{~Hz}, 1 \mathrm{H}), 3.96(\mathrm{~s}, 3 \mathrm{H}), 3.05(\mathrm{tt}, J=3.3,12.1 \mathrm{~Hz}, 1 \mathrm{H}), 2.08-1.14(\mathrm{~m}$, $10 \mathrm{H}) ;{ }^{13} \mathrm{C} \mathrm{NMR}\left(\mathrm{CDCl}_{3}, 75.5 \mathrm{MHz}\right) \delta 184.7,180.8,165.5,153.3,135.9,128.8,127.3,122.6$, 119.1, 111.2, 56.2, 35.3, 29.5, 27.0, 26.2; HRMS (EI) calcd. for $\mathrm{C}_{17} \mathrm{H}_{18} \mathrm{O}_{4} 286.1205$, found 286.1209.

Microwave-induced synthesis of 10 and 11. Adduct 6 (or 7) was evenly dispersed on the bottom of a $20 \mathrm{~mL}$ screw-cap vial, the lid was then loosely screwed on top of it. The vial was subjected to microwave heating for $2 \mathrm{~min}$. (Samsung MW1966WC oven, $1100 \mathrm{~W}$ ) and then allowed to cool to room temperature. A (2:1) hexanes/EtOAc solution (ca. $0.5 \mathrm{~mL}$ ) was added to the crude reaction mixture upon which a yellow solid precipitates. The mother liquor is removed to yield a yellow solid whose spectral properties match those of 10 (or 11) obtained by conventional heating and deprotection (29\% for $\mathbf{1 0}$ and $40 \%$ for $\mathbf{1 1})$.

\section{Acknowledgements}

Funding from the University of Guanajuato is greatly appreciated. R. S-A. wishes to thank the University of Guanajuato for a scholarship. 


\section{References}

1. Hudson, A. T.; Randall, A. W.; Fry, M.; Ginger, C. D.; Hill, B.; Latter, V. S.; McHardy, N.; Williams, R. B. Parasitology 1985, 90, 45.

2. Service, M.; Wardlaw, A. C.; Comp. Biochem. Physiol. 1984, 79B, 161.

3. Fieser, L. F.; Chang, F. C.; Dauben, W. G.; Heidelberger, C.; Heymann, H.; Seligman, A, M. J. Pharmacol. Exp. Ther. 1948, 94, 85.

4. Khambay, B. P. S.; Batty, D.; Cahill, M.; Denholm, I. J. Agric. Food Chem. 1999, 47, 770.

5. Mäntylä, A.; Garnier, T.; Rautio, J.; Nevalainen, T.; Vepsälainen, J.; Koskinen, A.; Croft, S. L.; Järvinen, T. J. Med. Chem. 2003, 47, 188.

6. Nair, V.; Treesa, P. M.; Maliakal, D.; Rath, N. P. Tetrahedron 2001, 57, 7705.

7. For a recent review, see Spyroundis, S. Molecules 2000, 5, 1291, also for a related study, see Chai, C. L. L.: Elix, J. A.; Moore, F. K. E. Tetrahedron Lett. 2001, 42, 8915.

8. Matsumoto, Y.; Tsuchida, T.; Nakamura, H.; Sawa, R.; Takahashi, Y.; Naganawa, H.; Inuma, H.; Sawa, T.; Takeuchi, T.; Shiro, M. Antibiot. 1999, 52, 276.

9. Ernst-Russel, M.; Elix, J.; Chai, C.; Willis, A.; Hamada, N.; Nash, T., III. Tetrahedron Lett. 1999, 40, 6321.

10. Harrity, J. P. A.; Kerr, W. J.; Midlemiss, D.; Scott, J. S. J. Organomet. Chem. 1997, 532, 219 and references cited therein.

11. Solorio-Alvarado, C. R.; Rodríguez-Cendejas, C. G.; Peña-Cabrera, E. ARKIVOC 2003, (xi), 172.

12. (a) Moore, H. W.; Yerxa, B. R. In Synthetic Utility of Cyclobutendiones; Halton, B., Ed.; JAI Press: Greenwich, CT, 1995; Vol. 4, p 81. (b) Liebeskind, L.S. Tetrahedron Symp. Print 1989, 45, 3053 (c) Koo, S.; Liebeskind, L. S. J. Am. Chem. Soc. 1995, 117, 3389 (d) Sun, L.; Liebeskind, L. S. J. Am. Chem. Soc. 1996, 118,12473 (e) Paquette, L. A.; Doussot, P. Res. Chem. Intermed. 1996, 22, 767 (f) Ohno, M.; Yamamoto, Y.; Eguchi, S. Synlett 1998, 1167 (g) Peña-Cabrera, E.; Liebeskind, L. S. J. Org. Chem. 2002, 67, 1689.

13. Liebeskind, L. S.; Fengl. R. W.; Wirtz, K. R.; Shawe, T. T. J. Org. Chem.1988, 53, 2482.

14. Foland, L. D.; Karlsson, J. O.; Perri, S. T.; Schwabe, R.; Xu, S. L.; Moore, H. W. J. Am. Chem. Soc. 1989, 111, 975.

15. Decomposition may have taken place during $\mathrm{SiO}_{2}$-gel chromatography. Variable yields of addition of aromatic organolithium reagents to squaric acid esters and cyclobutenediones are reported, see: (a) Kraus, J. L. Tetrahedron Lett. 1985, 26, 1867. (b) Gurski-Birchler, A.; Liu, F.; Liebeskind, L. S. J. Org. Chem. 1994, 59, 7737. 